УДК $94(47+477)$ «192...»

DOI: https://doi.org/10.33782/eminak2021.2(34).527

\title{
«КУЛЬТУРНА РЕВОЛЮЦІЯ» ПОЧАТКУ 1920-х рр., ЯК ТЕХНОЛОГІЯ ФОРМУВАННЯ РАДЯНСЬКОГО МЕНТАЛІТЕТУ
}

\author{
Борис Драмарецький1, Наталя Толубець² \\ ${ }^{1}$ Інститут української археографії та джерелознавства імені М.С. Грушевського \\ НАН України (Київ, Україна) \\ ORCID: https://orcid.org/0000-0003-3569-6784 \\ e-mail: dddboris@gmail.com \\ 2 Київський національний університет культури і мистецтв (Київ, Україна) \\ ORCID: https://orcid.org/0000-0002-9727-2648 \\ e-mail: tttalechka@gmail.com
}

\begin{abstract}
У статті досліджується технологія насадження ідеології, яку використовувала більшовицька влада на початку 1920-х рр. для формування «нового пролетарського світогляду». Реалізація поставлених задач означала заміну існуючого світогляду шляхом встановлення нових, офіційних правил і норм поведінки, які часто не відповідали елементарним потребам суспільства, знищенням мільйонів людей і побудову тоталітаризму. Метою такої політики було пограбування країни у нечуваних масштабах і повна залежність населення від більшовицьких вождів. Для цього недостатньо лише захопити політичну владу та керувати силовими структурами, а необхідно було змінити світогляд. I саме над цим варто задуматися нинішньому поколінню украӥнців.
\end{abstract}

Ключові слова: соціокультурне управління, комуністичний світогляд, ідеологія, культурна трансформація, менталітет, пропаганда, суспільне життя

Початок 1920-х років в радянській Україні позначився насадженням марксистської ідеології з метою повної зміни соціокультурного простору, який був направлений на побудову безкласового соціалістичного суспільства. «Нова людина» мала бути позбавленою індивідуальних рис, а її життєдіяльність підкорена єдиній меті досягненню конкретних (на які вказували партійні вожді - aвm.) політичних задач 1 .

Це актуально і сьогодні, адже значна кількість населення психологічно продовжує перебувати у радянському соціокультурному просторі, менталітету якого характерно: безвідповідальність, страх, беззахисність перед представниками влади, бюрократія, інертність (як політична, так і економічна), незнання своїх конституційних прав і невміння їх відстоювати, небажання працювати (до чого призвела «зрівнялівка»), заниження собівартості оплати праці, нерозуміння того, що держава існує для людей, а посадовці утримуються на податки населення й ін.

Тож позбутися нав'язаної більшовицькими «ідеологічними менеджерами» соціокультурної моделі світобачення, яка й понині підтримується посткомуністичними ідеологами як усередині країни, так і за ї̈ межами, вкрай необхідно не лише для

\footnotetext{
1 Борисенко М.В. Дозвілля міського мешканця України в добу сталінізму // Педагогічні та рекреаційні технології в сучасній індустрії дозвілля: матеріали Міжн. наук.-практ. конф., 4-6 черв. 2004 р. / укл.: В.В. Кірсанов, С.Д. Безклубенко; М-во освіти і науки України, М-во культури і мистецтв України, КНУКіМ. Київ: КНУКіМ, 2004. Ч. 1. С. 61-63.
} 
побудови реальних демократичних політичних інститутів, економічного росту, інтеграції до європейської та світової спільноти, а й існування державності.

Проблемі формування соціокультурного простору радянського суспільства міжвоєнного періоду присвячена значна кількість як узагальнюючих праць, так і спеціальних публікацій. Перші роботи з окресленого питання з'явилися ще у 1920ті pр. Вони спрямовувалися на роз'яснення більшовицької політики та її досягнення у соціокультурному будівництві. Авторами були радянські та партійні діячі, які доводили прогресивність соціалістичного будівництва, підносили значення його нового представника - пролетаря 2 . Одночасно, в ті роки вийшла значна кількість як радянських, так і закордонних видань, що були присвячені, як проблемі у цілому, так і конкретним ії аспектам.

Після утвердження тоталітарного режиму ідеологічний імператив був направлений на доказ того, що в процесі соціалістичних перетворень відбувається зближення народів СРСР, яке має завершитися створенням нової історичної спільноти - радянського народу, шляхом індустріалізації та на основі ленінсько-сталінської національної політики. Йшлося про створення «національної по формі та соціалістичної за змістом радянської культури». Дослідження стосувалися також соціальних процесів, створення та функціонування системи соціального забезпечення 3 .

У сучасній вітчизняній історіографії питанням життєдіяльності населення радянської України у процесі становлення тоталітарного режиму набуло нового поштовху. Актуальними проблемами досліджень для науковців стали соціокультурні процеси ${ }^{4}$, демографічна трансформація та етнонаціональні зміни населення5, а також повсякденні аспекти життєдіяльності 6 , соціальний захист ${ }^{7}$, девіантна поведінка ${ }^{8}$ й ін.

Однак, недостатньо висвітленими лишились такі важливі аспекти, як застосування технологій насадження комуністичного світобачення, вплив культурологічних чинників на формування радянського менталітету та закономірності соціокультурних змін.

Метою статmі є розкрити ідеологічні прийоми і технології, якими користувалася більшовицька влада початку 1920-х рр. з метою створення нового соціокультурного простору для управління життєдіяльністю суспільства.

Методологія дослідження полягає у використанні сукупності принципів і методів загального і спеціального характеру. Міждисциплінарний метод використову-

\footnotetext{
2 Див: Скрипник М.О. Статті й промови в справі національного будівництва. Т. 2. Ч. 1. Б.м.: Держвидав України, 1929. 360 с.; Затонський В. Національна проблема на Україні (Доповідь на пленумі ЦК ЛКСМУ, черв. 1926). Харків: Держвидав України, 1926. 64 с.) та ін.

3 Історія Української РСР / А.Г. Шевелєв, голов. ред. Київ, 1977. Т. 6. С. 24; Колісник М.К. Відновлення і зміцнення радянської влади на Україні (1919-1920). Харків, 1950. С. 140.

${ }^{4}$ Костюк $€$. Сучасна українська історіографія соціокультурних трансформацій у містах УСРР-УРСР упродовж 20-30-х рp. XX ст. // Вчені записки Таврійського національного університету імені B.I. Вернадського. Серія: Історичні науки. 2017. Т. 28 (67), № 2. С. 6.

${ }^{5}$ Алфьоров М. Демографічний розвиток міст Східної України в 1920-1939 рр. // Схід. 2009. № 8 (99), Листопад. С. 42-43.

6 Борисенко М.В. Дозвілля міського мешканця України в добу сталінізму... С. 61-63.

7 Шарпатий В.Г. Пенсійне забезпечення населення в УСРР 1920-30-х рр.: соціо-історичний дискурс // Україна XX ст.: культура, ідеологія, політика: Зб. статей. 2005. Вип. 8. С. 133-147.

8 Драмарецький Б. До питання вивчення проявів «соціальних відхилень» в містах Радянської України в 1920-1930рр. // «Університет»: науковий історико-філософський журнал. 2014. № 1-6. C. 54.
} 
вався для цілісного осмислення матеріалу, відобразив інтегративні тенденції історії, культурології та політології і надав можливість отримати нове знання при дослідженні окресленої теми. Принцип історизму дозволив визначити значення та місце комуністичної ідеології як інструменту управління при формуванні радянського суспільства на початку 1920-х рр. Структурний метод застосовувався в угрупованні та викладенні основних елементів управління соціокультурним простором і формування світобачення населення більшовиками.

Крім того, застосовано історико-генетичний, історико-порівняльний і проблемно-хронологічний методи, які дозволили виділити з об’єкта дослідження низку проблем і зрозуміти історичні особливості та специфічні риси культурного середовища початку 1920-х рр.

Виклад матеріалу дослідження. Культурна трансформація Радянської України початку 20-х рр. XX ст. мала чіткий ідеологічний зміст, означала виховання населення у комуністичному дусі та була направлена на створення нового пролетарського світогляду. Метою більшовицької культурної політики задекларовано побудову безкласового соціалістичного суспільства, формування людини нового типу «будівника комунізму». Натомість втілення цієї політики привела до побудови тоталітарного суспільства та знищення мільйонів людей ${ }^{9}$. Комуністична ідеологія у формі більшовицьких настанов, гасел, програмних документів, соціальноекономічної моделі й ін. мала стати всеохоплюючою та підмінити собою весь соціокультурний простір. Головними завданнями так званої «культурної революції» стало: знищення існуючих уявлень, понять, символів і традицій, а в разі неможливості - їхня підміна та нав'язування нових, більшовицьких традицій в усі сфери життя шляхом потужної ідеологічної пропаганди. Метою такої політики було пограбування населення країни та повна його залежність і контроль зі сторони більшовицьких вождів і створеними «караючими» структурами. У кого ж вистачало розуму цьому протидіяти або й просто розуміти, що відбувається маніпуляція зі свідомістю та підміна понять, тих розстрілювали, ув'язнювали, висилали.

3 початком захоплення влади в Росії, більшовицьке керівництво не змогло повністю змінити ментальність російського населення, основаного на християнстві, царизмі та общинному житті, відоме - за віру, царя і Вітчизну. Ще складніше було знищити світобачення українців, пов'язане не лише із православ'ям та язичницькими традиціями (колядки, Купала, русальні неділі й ін.), славетним козацьким минулим, а також із індивідуальним господарством, приватною власністю, підприємництвом - складовими ментальності українців.

Нав'язувалася ідеологія підміни, що стала потужною інформаційною зброєю для управління населенням в інтересах певного угрупування (більшовицького), що бажала захопити владу за будь-яку ціну, установити своє панування та контролювати «підкорених», знищуючи або підміняючи історичні факти, віру, традиції, народні свята, занурюючи населення у своє інформаційне поле. 3 комунізму почали робити нову релігію, побудовану на ідеології, символізмі та основних положеннях марксизму-ленінізму (згодом - ще й сталінізму). При цьому, власне світобачення нав'язувалося з нетерпимістю («зі всією пролетарською ненавистю»). Встановлювалися нові, офіційні правила та норми поведінки, які часто не відпові-

\footnotetext{
9 Костюк $Є$. Сучасна українська історіографія соціокультурних трансформацій у містах УСРР-УРСР упродовж 20-30-х pp. XX ст. // Вчені записки Таврійського національного університету імені B.I. Вернадського. Серія: Історичні науки. 2017. Т. 28 (67). № 2. С. 6.
} 
дали елементарним потребам суспільства та людини. Створена комуністична релігія потребувала беззаперечної віри, заснованої на прийнятті нових ідей або доктрин за абсолют, без будь-яких доказів. Адже віра сліпа, вона відключає свідомість. Віруючі «швондери» та «шарікови»10 страшні своїм фанатизмом і неспроможністю не лише зрозуміти, а й навіть вислухати інше бачення, іншу позицію. Жодні факти й аргументи на таких людей не діють. Вони неспроможні до критичного аналізу. Їх досить легко ввести в оману. І це прекрасно розуміли більшовицькі вожді, використовуючи такій потужний інструмент влади над людьми як комуністична ідеологія.

Одним із перших елементів управління соціокультурним простором і формування світобачення населення стала підміна існуючих християнських уявлень про рівність і рай. Використавши християнську ідею про рівність, більшовики впровадили «класову диктатуру пролетаріату як необхідного перехідного рівня до знищення класових відмінностей взагалі» ${ }^{11}$. А проявом проголошеної ідеї рівності стало знищення багатих (у пролетарському розумінні) людей. Почалася боротьба, у першу чергу, проти дворян, поміщиків і буржуазії, а потім продовжилася проти кваліфікованих робітників і селянства. Рушійною її силою став люмпенізований прошарок суспільства.

При цьому, рівність розумілася як суцільна бідність населення, що також стало своєрідною трансформацією християнської ідеї про «злиденних духом». Прекрасно розуміючи, що навряд чи людина може мріяти про жебрацтво, більшовики всіляко намагалися замінили і християнську віру про рай на своє бачення «загробного світу» - комунізм, де всі у майбутньому будуть духовно (ідейно) свідомими та матеріально багатими - «від кожного за здібностями, кожному за потребами». Таким чином, людина мала жити не реальним життям, а заради світлого майбутнього. Комунізм намагався відібрати сьогодення заради ілюзорного щастя для того, щоб захопити існуюче. А в подальшому також продовжувати забирати існуюче заради наступного майбутнього і так без кінця. Тож покращення відкладалося на невизначений термін. Робилося це ж, звичайно, у власних інтересах. Згадаймо хоча б величезний відрив між усіма рівнями життя (матеріального, соціального й ін.) номенклатури та пересічної людини. Йдеться не лише про соціальні верстви, проти яких вони боролися, а й про пролетаріат, який був проголошений гегемоном.

Відбулося жонглювання такими поняттями як «робітничий клас» і «пролетаріат», при якому перше підмінили другим, де меншість стала визначним для більшості, адже йшлося не про весь робітничий клас, а про люмпен-пролетаріат, безграмотний, що не мав майна, якому «немає чого втрачати, крім власних ланцюгів». I вже від його імені почали виступали більшовицькі лідери, проголосивши пролетаріат гегемоном і визначили його панівним класом, потреби якого мали визначати подальший шлях розвитку країни та суспільства у цілому.

Чому саме пролетаріат? Тому що ані дворянство, ані буржуазія (підприємці), ані духовенство, ані інтелігенція, ані, навіть, селянство їх підтримати не могли. Адже менталітет цих суспільних верств суттєво різнився від основних положень більшовизму. Очевидно, що заможних людей мало цікавив більшовицький рай у майбутньому. Вони жили щасливо вже сьогодні, чогось досягли тут і зараз. Окрім того,

10 Див: Булгаков М. Собаче серце. Київ: Book Chef, 2019.

11 Маркс К. Классовая борьба во Франции с 1848 по 1850 годы // Маркс К., Энгельс Ф. Сочинения. Москва: Государственное издательство политической литературы, 1955. Т. 7. С. 91. 
матеріально забезпечена людина - це незалежна особистість, а для тоталітарного режиму незалежні люди були загрозою і ворогами.

Саме тому пролетаріат стає інструментом для захоплення влади. Бо, по-перше, людьми, які не мають освіти, простіше маніпулювати; по-друге, пролетаріату була притаманна абсолютна відданість проголошеним ідеалам (згадаймо, як під час громадянської війни відбувалося знищення навіть найближчих родичів за політичними переконаннями); по-третє; віра в обіцянки успіху - «хто був ніким, той стане всім»; по-четверте, низи суспільства було легше очолити.

Збільшення чисельності пролетаріату, основною ознакою якого була відсутність власності й абсолютна відданість проголошеним гаслам, надавало можливості більшовицькому керівництву отримати абсолютну владу та зміцнити свою соціальну базу, впроваджувати політику суспільного прогресу, під яким розумілося цілковите економічне панування. Таким пануванням стала політика «воєнного комунізму».

Поставивши за мету зосередити у своїх руках ресурси i, водночас, забезпечити продуктами міське населення червоних столиць (у першу чергу - Петроград і Москва) та Червону армію, більшовики впровадили політику воєнного комунізму, широко використовуючи марксистське гасло - «експопріація експропріаторів», або ленінське - «грабуй награбоване». Таке насильницьке пограбування населення означало червоний терор, націоналізацію промисловості та великих сільськогосподарських маєтків, заборону вільної торгівлі, обмеження грошового обігу, примусову мобілізацію, насадження комун на селі та продрозверстку - експропріацію продовольства у селянства. А досягти цього можна було лише свідомо культивуючи та розпалюючи ненависть люмпенів до національної еліти для того, щоб за допомогою цього ж натовпу знищити стару еліту та самим посісти їі місце.

Наголосимо, що саме таке світобачення («відібрати й поділити» та «форсоване соціалістичне будівництво») було близьким до психології люмпенізованих верств суспільства, які намагалися, не дивлячись ні на що, штурмовими методами якомога швидше вирватися з труднощів.

Оскільки переважна частина пролетаріату зосереджувалася у містах, то одним iз першочергових завдань радянської влади стала побудова міст соціалістичного типу. Вони мали б відрізнятися від капіталістичних за всіма параметрами - від архітектури та розташування новобудов до суспільної організації. Важливим було й те, що у містах вироблявся основний інтелектуальний, інформаційний і культурний продукт. Окрім того, владний ідеологічний імператив розвитку міст мав показати, а, головне, довести прогресивність соціалістичного будівництва, піднести значення нового головного його мешканця - пролетаря 12.

Більшовицьке економічне панування у містах означало не лише націоналізацію промисловості, мілітаризацію господарства, встановлення державного контролю за виробництвом, уведення загальної трудової повинності, централізацію розподілу сировини та готової продукції і впровадження карткової системи розподілу продуктів, а й ліквідацію приватної власності на житло, яке ставало державним ${ }^{13}$.

\footnotetext{
12 Драмарецький Б. До питання вивчення проявів «соціальних відхилень»... С. 54.

13 Об отмене права частной собственности на недвижимость в городах: Декрет Всероссийского Центрального Исполнительного Комитета Советов рабочих, солдатских, крестьянских и казачьих депутатов. 20 августа 1918 г. // Собр. узаконений и распоряжений Рабочего и Крестьянского Правительства. 1918. № 2. С. 833-836.
} 
Відбираючи зароблене майно та значно занижуючи оплату праці, створені більшовиками відомства користувалися подвійною диференціацією у розподілі благ: мешканці міст поділялися на категорії в отриманні соціальної допомоги, наявною була перевага міста над селом 14 i, що важливо, житло почали використовувати як засіб примусу до роботи, дозволяючи виселення осіб, що належали за їхніми уявленнями до «нетрудових елементів», без надання іншого помешкання ${ }^{15}$. Ще однією маніпуляцією стала диференціація надання житла та роботи. Цими «благами», у першу чергу, наділялися найнижчі соціальні групи, наприклад, повії.

Таким чином, людину ставили в абсолютну залежність від представника влади, бо могли будь-кого з легкістю перетворити на безхатька чи жебрака. При цьому розподіляли зароблене цією ж людиною у власних інтересах і створювали міф про те, що держава надає населенню блага безкоштовно. Безкоштовна медицина, безкоштовна освіта, безкоштовне отримання житла і т. ін., що дає влада, - все це також міфи радянської пропаганди, які сформували рабську психологію залежності людини від держави, що відбилася у світобаченні. Якби населення отримувало заробітну плату, відповідну до рівня капіталістичних країн, в яких, за уявленнями більшовиків, «пригноблювали» трудящих, усіх цих подачок було б непотрібно, адже людина з легкістю могла б забезпечити собі все це самостійно. Підкреслимо, що «ненормальність» в оплаті праці, що була впроваджена у ті часи, зберігається й понині, коли людина, яка витратила роки життя для отримання освіти та підвищення професіоналізму отримує заробітну плату меншу ніж робітник з низькою кваліфікацією.

У сільській місцевості експропріація означала «викачування» хліба силовими методами із загальною відповідальністю населення перед владою. Складалися «чорні списки» (до них часто зараховувалися цілі села) та запроваджувалася система заручників. Працівники Наркомпроду УСРР мали у своєму розпорядженні навіть кавалерійські частини для придушення опору селян й охорони продовольчих вантажів. Організовувалися загороджувальні загони, що боролися з мішечництвом на транспорті. А для кращого проведення конфіскацій РКП(б) запровадила в Україні Комітети незаможних селян (комнеземи). Більша частина з них - це «загальновідомі типи сільськогосподарських голодранців, які «не орють і не сіють», а тільки живуть 3 дня на день»16. Вони звільнялись від розверстки і мали право привласнювати собі від 10\% до 25\%17 з награбованого. Крім розкладки, під приводом розкуркулення більшовики часто забирали усе майно та продовольство у заможних і «неблагонадійних» верст населення, іноді - з особистих причин. Нерідко викидали господарів на вулицю з власної хати ${ }^{18}$. Таким чином, використовуючи заздрість до тих, хто уже чогось досягнув, створювалися умови для збільшення сільського пролетаріату.

Однак, насильницьке насадження політичної та економічної влади більшовиків викликало запеклу боротьбу усіх верств населення. Йдеться не лише про прихильників незалежної української державності, дворян, підприємців та ін., але й робі-

\footnotetext{
14 Шарпатий В.Г. Пенсійне забезпечення населення в УСРР 1920-30-х рр.... С. 133-147.

15 Алфьоров М. Демографічний розвиток міст Східної України в 1920-1939 рр.... С. 42-43.

16 Герасимович I. Голод на Україні. Берлін, 1922. С. 49-50.

17 Колісник М.К. Відновлення і зміцнення Радянської влади на Україні (1919-1920). Харків, 1950.

C. 140.

18 Герасимович І. Голод на Україні... С. 54-55.
} 
тників і селянства. Зростала кількість повстань і страйків. Повстанський рух поглиблювався, проникав до лав Червоної армії, блокував роботу державних господарських органів, промислових підприємств, транспорту19. Часто страйкували робітники через низьку зарплату або її затримку, через нестачу продовольства 20.

29 січня 1921 р. приймається постанова «Про заходи по боротьбі з бандитизмом»21. Вона мала здійснюватися міліцією та ОДПУ, а в селах регулярними військами та озброєними загонами комнеземів, підпорядкованих міліції. Але, застосування військової сили не зменшувало розмаху повстань. Так, у постанові Раднаркому УСРР від 1 лютого 1921 р. зазначалося, що «боротьба проти «бандитизму» ведеться тільки військовими заходами, які призводять до знищення живої сили «бандформувань» і не усувають корінних причин їх утворення» 22 . Тому, для посилення ефективності використовували варварську практику утримання заручників з числа тих селянських сімей, члени яких підтримували повстанців.

Жорстка нетерпимість будь-кого - від наклепів і виселення до тюремного ув'язнення та фізичного знищення людини й таврування усіх її близьких і родичів, як і протилюдські заходи, направлені на приборкання повстань, не мали жодних успіхів, адже не була усунута головна причина - експропріація та соціалістичні експерименти правлячої партії, направлені проти традиційного укладу життя українців, їхнього права на власність, права на незалежне господарювання, права на своє світобачення. Ситуація склалася настільки загрозлива, що Рада Праці та Оборони, очолювана В.І. Леніним, вказувала, що «ліквідація бандитизму є питанням життя і смерті для радянської України»23. Фактично йшлося про те, що населення зненавиділо людей, які досягли найвищої політичної влади, прикриваючись демагогією про мир, рівність, соціальні блага, але фактично впровадили політичний, економічний і соціокультурний терор.

Наслідком стало те, що Ленін був змушений визнати провал політики воєнного комунізму і необхідність тимчасових поступок, особливо на користь селянства, й у 1921 р. приймається НЕП. Це означало фактичне повернення до ринку і повстанський рух почав втрачати масовість.

Однак, від ідеології, як інструменту контролю над населенням, більшовики відмовлятися і не думали. На фоні знищення «старого» світосприйняття насаджувалася: класова ненависть до ворогів (зазвичай до тих, на кого вкаже партія), відданість комуністичним ідеям, віра у мудрість влади та культ вождя. Радянська людина мала також мати надлюдську працездатність і готовністю до самопожертви заради «високої мети». Така маніпуляція свідомістю призвела до того, що населення більше переймалося глобальними проблемами світового пролетаріату та поширення комунізму ніж власним безправ'ям, жебрацьким станом і працею на межі фізичного виснаження. А згодом повернулися й до «терору економічного»24. Це втілив уже Сталін, впровадивши мілітаризацію, індустріалізацію та колективізацію.

\footnotetext{
19 Орлинский А.Р. Бандитизм и борьба с ним // Армия и революция. 1921. № 2. С. 15.

20 Центральний держархів громадських об'єднань України. Ф. 3204. Оп. 2. Спр. 11. Арк. 12.

21 Центральний держархів вищих органів влади та управління України. Ф. 257. Оп. 1. Спр. 17. Арк. 8.

22 Маскудов С. Документи з архіву ОДПУ 1921-1927 pp. // Український історичний журнал. 1992. № 2. С. 103.

23 Історія Української РСР... С. 24.

24 Ленин В.И. Полное собрание сочинений. Москва: Издательство политической литературы, 1970. Т. 44. С. 428.
} 
Висновки. Таким чином, на початку 1920-х років мешканцям «Великої країни рад» була насаджена політика, направлена на абсолютну залежність населення від більшовицької верхівки. Йдеться не лише про політичну та економічну залежність. Важливим стала зміна традиційного світобачення та нав'язування ідеології, яка мала підмінити собою культуру й отримала назву «культурної революції». Ї̈̈ складовими стали: 1) ідея християнської рівності розумілася як суцільна бідність і означала знищення багатих, адже матеріально забезпечена людина - це незалежна людина, яка автоматично перетворювалася на ворога тоталітарного режиму; 2) віра у рай була замінена на віру у комунізм для того, щоб люди жили не реальним життям, а заради світлого майбутнього; 3) відбулася підміна поняття «робітничий клас» на «пролетаріат». Фактично йшлося про низи суспільства - люмпенів, тобто на тих, хто не мав ніякого майна і не мав освіти, оскільки такими людьми легше маніпулювати, зробивши із них фанатичних прихильників; 4) боротьба із тими, хто не погоджувався сприймати більшовицьку ідеологію проводилася не лише шляхом терору, а й перекручуванням фактів і маніпулюванням поняттями.

Комуністичний світогляд насаджувався також і в ідеях інтернаціонального виховання (світова революція, пролетарі усіх країн об’єднуйтесь, радянське суспільство), а такому мисленню байдуже до національних і державних інтересів.

Наголосимо, що особисте життя комуністичних вождів не було бідним. Вони вели розкішне життя, мали можливість жити у величезних палацах, а їхні нащадки й понині живуть у США і провідних країнах Європи. Тож викликає сумнів в «ідейності» більшовицьких вождів, їхній «відданості» світовій революції, пролетаріату, комунізму тощо. Йдеться про грабунок країни у нечуваних масштабах, а для цього недостатньо лише захопити політичну владу та керувати силовими структурами. Необхідно було змінити світогляд населення, його ментальність. I саме над цим варто задуматися нинішньому поколінню українців.

У даній розвідці окреслені лише деякі із важливих аспектів «культурної революції». Однак культурна трансформація проявлялася майже на всіх рівнях суспільного життя та відбувалася у подальшому. Тож, ці та багато інших питань щодо радянської культури, менталітету, світосприйняття, роботи ЗMI, пропаганди й ін. потребують подальших розробок.

\section{REFERENCES}

Alfiorov, M. (2009). Demohrafichnyi rozvytok mist Skhidnoi Ukrainy v 1920-1939 rr. [Demographic development of Eastern Ukraine cities in 1920-39]. Skhid, 8 (99), $42-43$ [in Ukrainian].

Borysenko, M.V. (2004). Dozvillia miskoho meshkantsia Ukrainy v dobu stalinizmu [Leisure of a Ukrainian city dweller in the Era of Stalinism]. In: Proceedings of the Conference «Pedahohichni ta rekreatsiini tekhnolohii v suchasnii industrii dozvillia» (4-6.06.2004), (Vol.1, pp. 61-63). Kyiv: KNUKiM [in Ukrainian].

Bulhakov, M. (2019). Sobache sertse [The Dog's Heart]. Kyiv: Book Chef [in Ukrainian].

Dramaretskyi, B. (2014). Do pytannia vyvchennia proiaviv «sotsialnykh vidkhylen» v mistakh Radianskoi Ukrainy v 1920-1930 rr. [On the question of studying the manifestations of «social deviations» in the cities of Soviet Ukraine]. Universytet: naukovyi istoryko-filosofskyi zhurnal, 1-6, 52-56 [in Ukrainian].

Herasymovych, I. (1922). Holod na Ukraini [Hunger in Ukraine]. Berlin [in Ukrainian].

Kolisnyk, M.K. (1950). Vidnovlennia i zmitsnennia Radianskoi vlady na Ukraini (1919-1920) [Recovery and strengthening of Soviet Power in Ukraine (1919-1920)]. Kharkiv [in Ukrainian].

Kostiuk, Ye. (2017). Suchasna ukrainska istoriohrafiia sotsio-kulturnykh transformatsii u mistakh USRR-URSR uprodovzh 20-30-kh rr. XX st. [Contemporary Ukrainian historiography of socio-cultural transformations in the cities of the Ukrainian SSR - USSR]. Vcheni zapysky Tavriiskoho natsionalnoho universytetu imeni V.I. Vernadskoho. Seriia: Istorychni nauky, Vol. 28 (67), No 2, P. 6-12 [in Ukrainian]. 
Lenin, V.I. (1970). Polnoe sobranie sochinenii [Collected works]. Moskva: Izdatelstvo politicheskoi literatury, Vol. 44 [in Russian].

Marks, K. \& Engels, F. (1955). Sochineniia [Works], Vol. 7. Moskva [in Russian].

Maskudov, S. (1992). Dokumenty z arkhivu ODPU [Documents from the ODPU archive, 1921-1927]. Ukrainskyi istorychnyi zhurnal, 2, 100-111 [in Ukrainian].

Orlinskii, A.R. (1921). Banditizm i borba s nim [Banditry and the fight against it]. Armiia i revoliutsiia, 2/3, 3-16 [in Russian].

Sharpatyi, V.H. (2005). Pensiine zabezpechennia naselennia v USRR 1920-30-kh rr.: sotsio-istorychnyi dyskurs [Pension provision of the population in the Ukrainian SSR of 1920-30: socio-historical discourse]. Ukraina XX st.: kultura, ideolohiia, polityka, 8, 133-147 [in Ukrainian].

Sheveliev, A.H. (Ed.) (1977). Istoriia Ukrainskoi RSR [History of the Ukrainian SSR]. Vol. 6, Kyiv [in Ukrainian].

Skrypnyk, M.0. (1929). Statti i promovy v spravi nacionalnoho budivnytstva [Articles and speeches on nation-building]. Vol. 2, Part 1. Kharkiv [in Ukrainian].

Zatonskyi, V. (1926) Natsionalna problema na Ukraini [The national problem in Ukraine]. Kharkiv: Derzhvydav Ukrainy [in Ukrainian].

\section{Boris Dramaretskiy}

(M.S. Hrushevsky Institute of Ukraine Arheography and Source Studies, Kyiv, Ukraine)

e-mail: dddboris@gmail.com

ORCID: https://orcid.org/0000-0003-3569-6784

\section{Natalia Tolubets}

(Kyiv National University of Culture and Arts, Kyiv, Ukraine)

e-mail: tttalechka@gmail.com

ORCID: https://orcid.org/0000-0002-9727-2648

\section{‘Cultural Revolution' of Early 1920s as a Technology for Soviet Mentality Formation}

The change of social and cultural environment by the Bolshevik regime in Ukraine in the early 1920s and the formation of the Soviet mentality are studied in the paper. Getting rid of the psychology of the social and cultural worldview model imposed by the Bilshovyk ideological managers', which is even nowadays supported by post-communist ideologues both inside and outside this country, is essential not only for establishing real democratic political institutions, economic growth, integration into European and world community, but also for the existence of statehood. The goal of the paper is to reveal the ideological methods and techniques used by the Bilshovyk power in the early 1920s in order to create a new worldview as well as a new social and cultural environment in order to rule the society's life.

It is proved that in Ukraine in the early 1920s, Bilshovyk ideology replaced traditional notions and imposed new ones, whereas the struggle against dissenting views was conducted by applying red terror, distortion of facts, and outright manipulation. In particular, the belief in paradise was replaced by the belief in communism in order to deprive the population of reality for the sake of illusory happiness in the future. At the same time, the idea of Christian equality was understood as everybody's poverty. The notion 'working class' was replaced by the 'proletariat', as the latter was easier to manipulate, making people fanatical supporters. The communist worldview was also implanted in the ideas of international education, and such thinking is, as a rule, indifferent to national and state interests. It should be noted that personally, the communist leaders lived a luxurious life, had huge collections, palaces, millions of wealth in American and European banks, and their descendants still live in the United States and European countries. Therefore, it gives rise to doubt about the 'ideology' of the Bilshovyk leaders, their 'devotion' to the world revolution, the proletariat, communism, and so on. It was a matter of plundering the country on an unprecedented scale, and it was not enough just to seize political power and run the security forces. It was necessary to change the worldview of the population, its mentality, which was characterized by: irresponsibility, fear, 
vulnerability to government officials, bureaucracy, inertia, unwillingness to work, underestimation of labor costs, ignorance of personal constitutional rights, and misunderstanding that the state exists for people and officials got salaries from taxes. And this is exactly what the current generation of Ukrainians should think about.

Keywords: social and cultural management, communist worldview, ideology, cultural transformation, mentality, propaganda, public life 